ISSN 1678-3921

Journal homepage: www.embrapa.br/pab

For manuscript submission and journal contents, access: www.scielo.br/pab

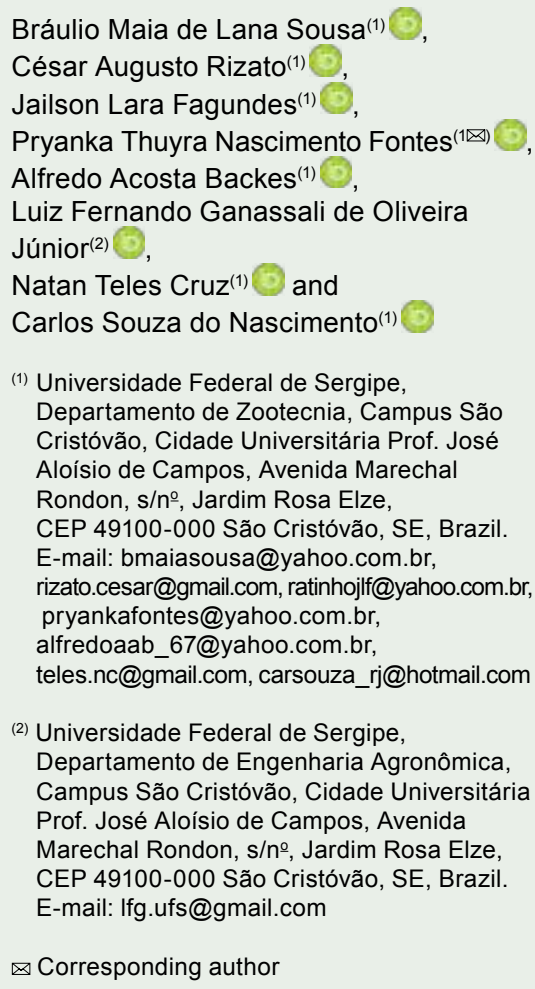

Received

March 22, 2018

Accepted

October 10, 2018

How to cite

SOUSA, B.M. de L.; RIZATO, C.A.;

FAGUNDES, J.L.; FONTES, P.T.N.; BACKES, A.A.; OLIVEIRA JÚNIOR, L.F.G. de; CRUZ, N.T.; NASCIMENTO, C.S. do. Tillering dynamics of digit grass subjected to different defoliation frequencies. Pesquisa Agropecuária Brasileira, v.54, e00668, 2019. DOI: https://doi. org/10.1590/S1678-3921.pab2019.v54.00668.

\section{Tillering dynamics of digit grass subjected to different defoliation frequencies}

\begin{abstract}
The objective of this work was to evaluate the tillering dynamics of 'Suvernola' digit grass (Digitaria eriantha) when subjected to different defoliation frequencies. Four defoliation frequencies (interval among harvests) were evaluated - very high, when the grass reached $25 \mathrm{~cm}$ in height; high, $35 \mathrm{~cm}$; medium, $45 \mathrm{~cm}$; and low, $55 \mathrm{~cm}$ - in two seasons of the year, with higher and lower insolation, from January 2015 to January 2016. A randomized complete block design with four replicates was used. The increase in defoliation frequency increased the number of generations and the appearance, mortality, and density rates of tillers, besides decreasing their survival rate, without changing population stability. At the time of lower insolation, tiller appearance and mortality rates were higher, while tiller survival rate, balance, and density were lower. The evaluated defoliation frequencies and seasons of the year do not change the persistence of digit grass when irrigated. Higher defoliation frequencies result in a greater renewal of digit grass tillers.
\end{abstract}

Index terms: Digitaria eriantha, harvest height, pasture persistence.

\section{Dinâmica do perfilhamento do capim faixa-branca submetido a diferentes frequências de desfolhação}

Resumo - O objetivo deste trabalho foi avaliar a dinâmica do perfilhamento do capim faixa-branca 'Suvernola' (Digitaria eriantha) quando submetido a diferentes frequências de desfolhação. Quatro frequências de desfolhação (intervalo entre cortes) foram avaliadas - muito alta, quando a gramínea atingiu $25 \mathrm{~cm}$ de altura; alta, $35 \mathrm{~cm}$; média, $45 \mathrm{~cm}$; e baixa, $55 \mathrm{~cm}-$ em duas épocas do ano, com maior e menor insolação, de janeiro de 2015 a janeiro de 2016. Utilizou-se o delineamento em blocos ao acaso, com quatro repetições. A elevação na frequência de desfolhação aumentou o número de gerações e as taxas de aparecimento, mortalidade e densidade populacional de perfilhos, além de reduzir sua taxa de sobrevivência, sem alterar a estabilidade da população. No período de menor insolação, as taxas de aparecimento e de mortalidade de perfilhos foram maiores, enquanto a taxa de sobrevivência, o balanço e a densidade populacional de perfilhos foram menores. As frequências de desfolhação e as épocas do ano avaliadas não alteram a persistência do capim faixa-branca quando irrigado. Maiores frequências de desfolhação resultam em maior renovação de perfilhos do capim faixa-branca.

Termos para indexação: Digitaria eriantha, altura de colheita, persistência da pastagem. 


\section{Introduction}

The feeding of ruminants in Brazil is based on the use of pastures, which are mostly managed improperly. This inadequate management may stem from a lack of knowledge by the producer and/or a lack of consistent management-related information for certain forage grass species, such as digit grass, previously known as Digitaria umfolozii, but recently reclassified as Digitaria eriantha 'Suvernola' (Cook \& SchultzeKraft, 2015).

Digit grass is a C4 plant (Gusmão Filho, 2018), more commonly grown in Northeastern Brazil, mainly in the states of Sergipe and Alagoas (Souza et al., 2016). This grass is adapted to regions of low mean temperature, low precipitation, and soils with low natural fertility (Navarro et al., 2005), although it appears to be responsive to irrigation (Oliveira et al., 2015) and nitrogen fertilization (Souza et al., 2016). The species presents crude protein content between 10 and 15\% (Gusmão Filho, 2018) and 59\% total digestible nutrients (Oliveira et al., 2015), indicating its potential for usage in pastures.

For a tiller population to be considered stable, there should be a balance between tiller death and appearance (Sbrissia \& Silva, 2014). Long periods of death in relation to appearance may compromise the productivity and the persistency of the forage plant. Therefore, understanding the population dynamics of the plants in a pasture through alterations in tiller appearance, density, survival, and mortality (Silva et al., 2008) is important in helping to define more adequate management practices.

The objective of this work was to evaluate the tillering dynamics of 'Suvernola' digit grass when subjected to different defoliation frequencies.

\section{Materials and Methods}

The experiment was conducted in the municipality of São Cristóvão, in the state of Sergipe, Brazil (11²2'S, $37^{\circ} 12^{\prime} \mathrm{W}$, at $47 \mathrm{~m}$ above sea level), from January 2015 to January 2016. According to Köppen's classification, the climate of the region is tropical, of the Awa type, with dry and rainy seasons from September to March and from April to August, respectively. The average annual temperature is $25.6^{\circ} \mathrm{C}$, and the average annual rainfall is $1,409 \mathrm{~mm}$. The collected climatic data were: monthly means of insolation; minimum, average, and maximum temperatures; and precipitation (Figures 1 $\mathrm{A}$ and $\mathrm{B})$.

The soil of the experimental area was classified as a Neossolo Quartzarênico (Santos et al., 2006), i.e., a Typic Quartzipisamment, of sandy texture and plain relief, with the following chemical properties: $\mathrm{pH}\left(\mathrm{H}_{2} \mathrm{O}\right) 5.49,3.90 \mathrm{mg} \mathrm{dm}^{-3} \mathrm{P}$ (Mehlich-1), $138 \mathrm{mg}$ $\mathrm{dm}^{-3} \mathrm{~K}, 0.38 \mathrm{cmol}_{\mathrm{c}} \mathrm{dm}^{-3} \mathrm{Ca}, 0.35 \mathrm{cmol}_{\mathrm{c}} \mathrm{dm}^{-3} \mathrm{Mg}, 1.24$ $\mathrm{cmol}_{\mathrm{c}} \mathrm{dm}^{-3} \mathrm{H}+\mathrm{Al}$, base saturation of $1.21 \%$, cationexchange capacity at $\mathrm{pH} 7.0$ of $2.45 \mathrm{cmol}_{\mathrm{c}} \mathrm{dm}^{-3}$, and $11.8 \mathrm{~g} \mathrm{dm}^{-3}$ organic matter. Subsequently, soil fertility amendments were performed according to soil needs and the requirements of the studied forage plant. In this case, $100 \mathrm{~kg} \mathrm{ha}^{-1} \mathrm{P}_{2} \mathrm{O}_{5}$ were applied as single superphosphate, $100 \mathrm{~kg} \mathrm{ha}^{-1} \mathrm{~K}_{2} \mathrm{O}$ as potassium chloride, and $60 \mathrm{~kg} \mathrm{ha}^{-1} \mathrm{~N}$ as urea, in a single application.

The evaluated forage was $D$. eriantha 'Suvernola', established in a $102-\mathrm{m}^{2}$ area. From August to December 2014, the forage plant was irrigated regularly to the field capacity of the soil, harvested at a height of $40 \mathrm{~cm}$, and lowered to a residual height of $10 \mathrm{~cm}$ thereafter. In January 2015, a uniformity harvest was performed when all plots were lowered to $10 \mathrm{~cm}$, marking the onset of evaluations.

Treatments consisted of four defoliation frequencies very high, when the grass reached $25 \mathrm{~cm}$ in height; high, $35 \mathrm{~cm}$; medium, $45 \mathrm{~cm}$; and low, $55 \mathrm{~cm}$ - evaluated in two periods of the year with higher and lower insolation. The periods of higher insolation were from 1/21/2015 to $3 / 31 / 2015$ and from $9 / 1 / 2015$ to $1 / 15 / 2016$, and of lower insolation, from $4 / 1 / 2015$ to $8 / 31 / 2015$. The experimental design was a randomized complete block with four replicates. The usable area of each experimental unit (plot) corresponded to $4.69 \mathrm{~m}^{2}(2.6 \times 1.8 \mathrm{~m})$.

Fertilization was carried out using $300 \mathrm{~kg} \mathrm{ha}^{-1}$ per year of nitrogen, in the form of ammonium, as recommended by Souza et al. (2016) for digit grass, and also $240 \mathrm{~kg} \mathrm{ha}^{-1}$ per year of potassium in the form of potassium chloride. Fertilization was split into three applications, performed at the intervals between each harvest, following Sousa et al. (2013); at the end of the entire experimental period, all plots had received the same amount of fertilizer. Digit grass height, corresponding to the average of four points per experimental unit, was determined twice a week with a ruler.

At the start of the experiment in January 2015, two tussocks were marked at random per plot. All tillers within each tussock were counted and marked 
by different colored plastic-coated wire. After each defoliation, all marked tillers were counted again; new tillers were marked with a different color from that used in the previous markings, and the wires around dead tillers were removed. This way, it was possible to estimate the tiller population of all generations and to calculate appearance rate [(flowered tillers/ total live tillers at the previous tagging) $\times 100$ ], mortality rate $[(\mathrm{dead}$ tillers/total live tillers at the previous tagging $) \times 100$ ], survival rate $(100-$ tiller mortality rate), balance between tiller appearance and mortality (tiller appearance - mortality rate), and tiller population stability index [tiller survival rate $\times(1+$
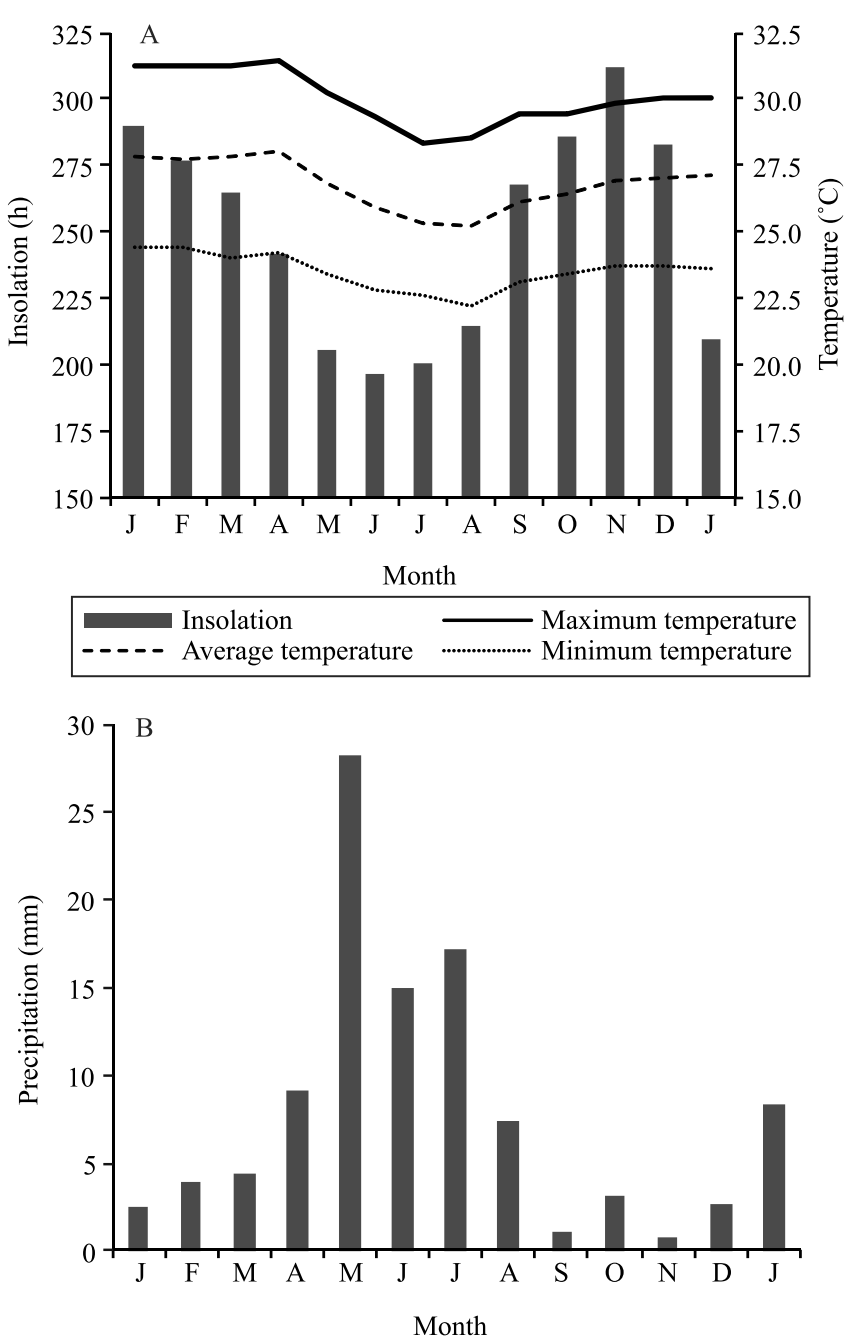

Figure 1. Total monthly insolation together with minimum, average, and maximum temperatures (A) and total monthly precipitation (B) in the period from January 2015 to January 2016. tiller appearance rate)]. Basal and nodal tiller densities (tillers per square meter) were estimated by counting all basal and nodal tillers within a $0.25-\mathrm{m}^{2}$ metal frame that was allocated at random in each experimental unit; this count of live tillers was carried out before each harvest.

The data were analyzed by the analysis of variance, at $5 \%$ probability, using the Proc Mixed (mixed models) option of the SAS statistical package (SAS Institute Inc., Cary, NC, USA). Means were compared by Student's t-test, at 5\% probability. Tiller appearance, mortality, and survival rates, as well as balance between tiller appearance and mortality, population stability index, and population density, were determined using the following model: $Y_{i j k}=\mu+A_{i}+E_{j}+A_{i j}+B_{k}+e$, where $Y_{i j k}$ is the observed value of height $i$, time $j$, and block $\mathrm{k} ; \mu$ is the overall constant (population mean); $\mathrm{A}_{\mathrm{i}}$ is the effect of defoliation frequency $\mathrm{i}(\mathrm{i}=1,2,3,4)$; $E_{j}$ is the effect of season of the year $j(j=1,2) ; A E_{i j}$ is the frequency $\mathrm{i} \times$ time $\mathrm{j}$ interaction; $\mathrm{B}_{\mathrm{k}}$ is the effect of block $\mathrm{k}(\mathrm{k}=1,2,3,4)$; and $\mathrm{e}$ is the error. In this model, $A_{i}, E_{j}, A_{i j}$, and $B_{k}$ were tested.

\section{Results and Discussion}

The obtained defoliation frequencies were close to the targeted heights, averaging $26.2 \mathrm{~cm}$, very high; $35.5 \mathrm{~cm}$, high; $45.8 \mathrm{~cm}$, medium; and $54.4 \mathrm{~cm}$, low. Because all harvests were performed up to the postharvest residual height of $10 \mathrm{~cm}$, it was not possible to monitor the tillering dynamics of the nodal tillers, given that they are located on the upper part of the sward and eliminated during defoliation.

As defoliation frequency was reduced, there was a decrease in the number of harvests during the experimental period (Figure 2): 17 harvests for the very high defoliation frequency, 13 harvests for the high one, 10 harvests for the medium one, and only 9 harvests for the low one.

Since the residual post-harvest height was the same for all treatments, i.e., $10 \mathrm{~cm}$, digit grass defoliated at lower frequencies showed a longer regrowth time than that defoliated at higher frequencies, which explains the reduced number of harvests. This pattern allowed obtaining an even greater number of tiller generations at the higher defoliation frequencies, which indicates a greater tissue renewal and, consequently, a younger tiller population in the pasture. Young tillers may 
present higher appearance and leaf elongation rates (Barbosa et al., 2012), a higher number of live and expanding leaves, and a lower number of senescent leaves in relation to older tillers (Paiva et al., 2012). This younger population may result in qualitative gains by improving plant nutritional value (Voltolini et al., 2010) and, therefore, animal performance (Gimenes et al., 2011).

Tiller appearance and mortality rates were influenced by defoliation frequencies and times of the year. As defoliation frequencies decreased, so did tiller appearance and mortality rates (Figure $3 \mathrm{~A}$ and C). This response pattern has also been recorded for various forage grasses, such as Marandu (Difante et al.,
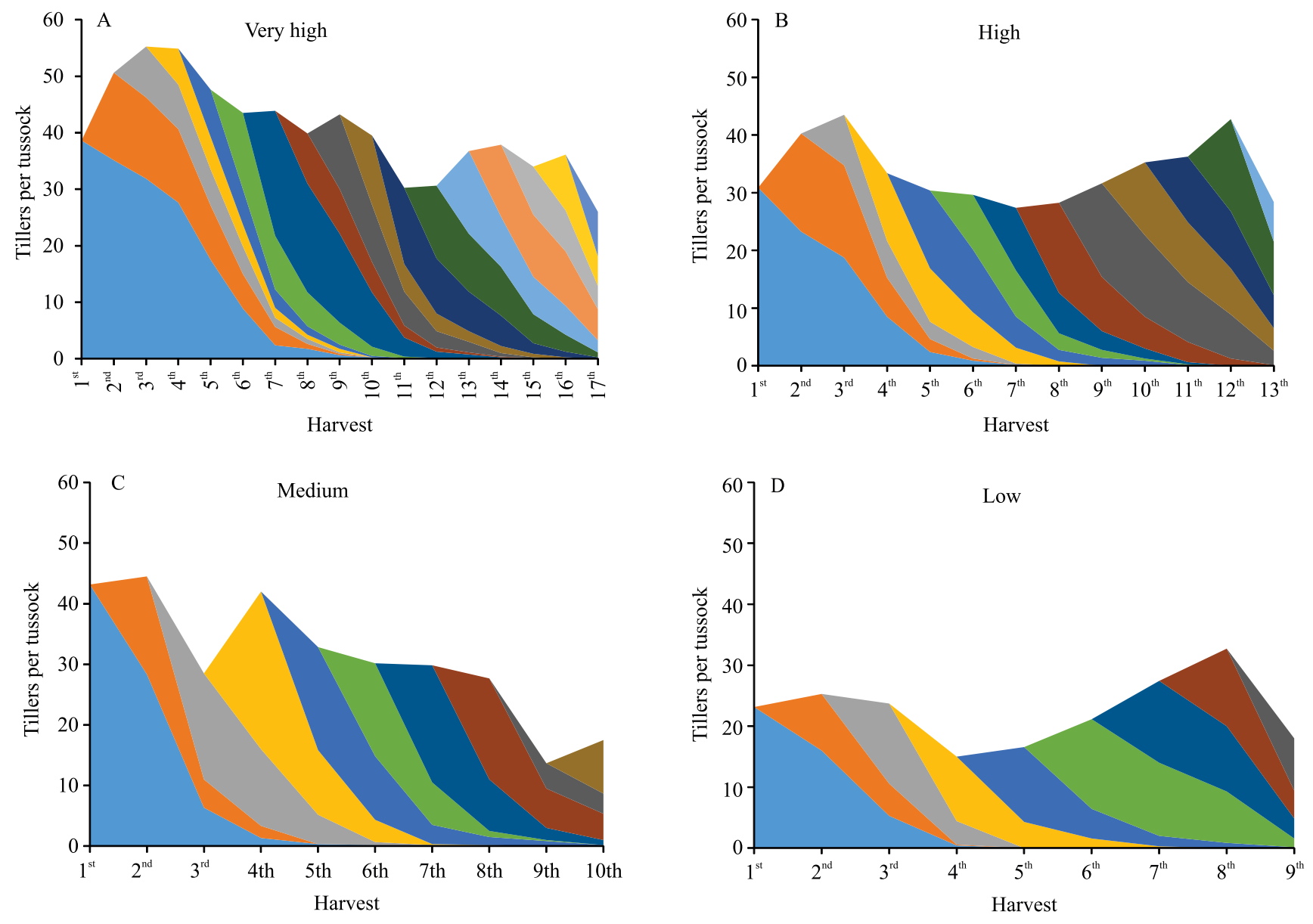

$$
\begin{aligned}
& \square 1^{\text {st }} \text { gen } \square 2^{\text {nd }} \text { gen } \square 3^{\text {rd }} \text { gen } \square 4^{\text {th }} \text { gen } \square 5^{\text {th }} \text { gen } \square 6^{\text {th }} \text { gen } \square 7^{\text {th }} \text { gen } \square 8^{\text {th }} \text { gen } \square 9^{\text {th }} \text { gen } \\
& \square 10^{\text {th }} \text { gen } \square 11^{\text {th }} \text { gen } \square 12^{\text {th }} \text { gen } \square 13^{\text {th }} \text { gen } \square 14^{\text {th }} \text { gen } \square 15^{\text {th }} \text { gen } \square 16^{\text {th }} \text { gen } \square 17^{\text {th }} \text { gen }
\end{aligned}
$$

Figure 2. Basal tiller population dynamics of 'Suvernola' digit grass (Digitaria eriantha) subjected to the following defoliation frequencies: very high, $25 \mathrm{~cm}$ in height (A); high, $35 \mathrm{~cm}$ (B); medium, $45 \mathrm{~cm}$ (C); and low, $55 \mathrm{~cm}$ (D). Gen, tiller generation. 
Likewise, tiller survival was influenced by defoliation frequencies and seasons of the year. The reduction in defoliation frequencies elevated the tiller survival rate (Figure $4 \mathrm{~A}$ ), which was greater in the season of higher insolation (Figure $4 \mathrm{~B}$ ).

Pasture productivity and persistence are partially influenced by the survival of forage grasses in the plant community (Caminha et al., 2010). Although survival is a trait determined genetically, the availability of environmental growth factors (precipitation, luminosity, temperature, and soil fertility, among others), together with the strategies used for defoliation, may change the renewal patterns and capacity of tillers in the pasture (Matthew et al., 2000). In the present study, digit grass defoliated at higher frequencies showed a lower tiller survival rate (Figure $4 \mathrm{~A}$ ), attributed to the higher tiller appearance and mortality rates (Figures $3 \mathrm{~A}$ and $\mathrm{C}$ ). This too resulted in a greater
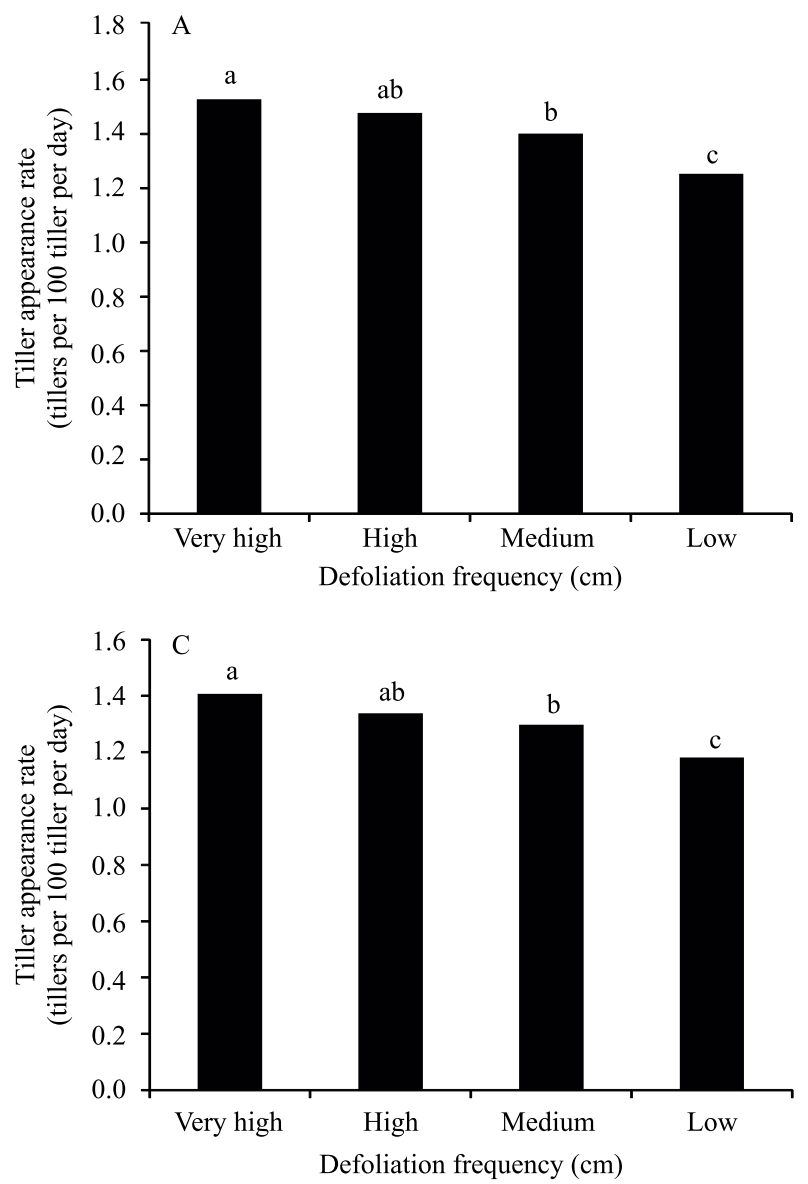

tiller renewal, i.e., a higher number of generations (Figure 2), in comparison with the grass defoliated at lower frequencies.

It is important to highlight that the lower survival rates (Figure $4 \mathrm{~A}$ ) recorded for digit grass defoliated at higher frequencies did not indicate a lower persistence of this forage grass. In this case, persistence is better evaluated through the population stability index (Difante et al., 2008) and the balance between tiller appearance and mortality rates.

The population stability index of digit grass at the different defoliation frequencies varied during the entire experimental period, with values fluctuating around 1.0 (Figure 5). The balance between tiller appearance and mortality, however, was not influenced by defoliation frequency, revealing an average positive result of 0.1089 tillers per 100 tillers per day. A stability index greater than 1.0 indicates
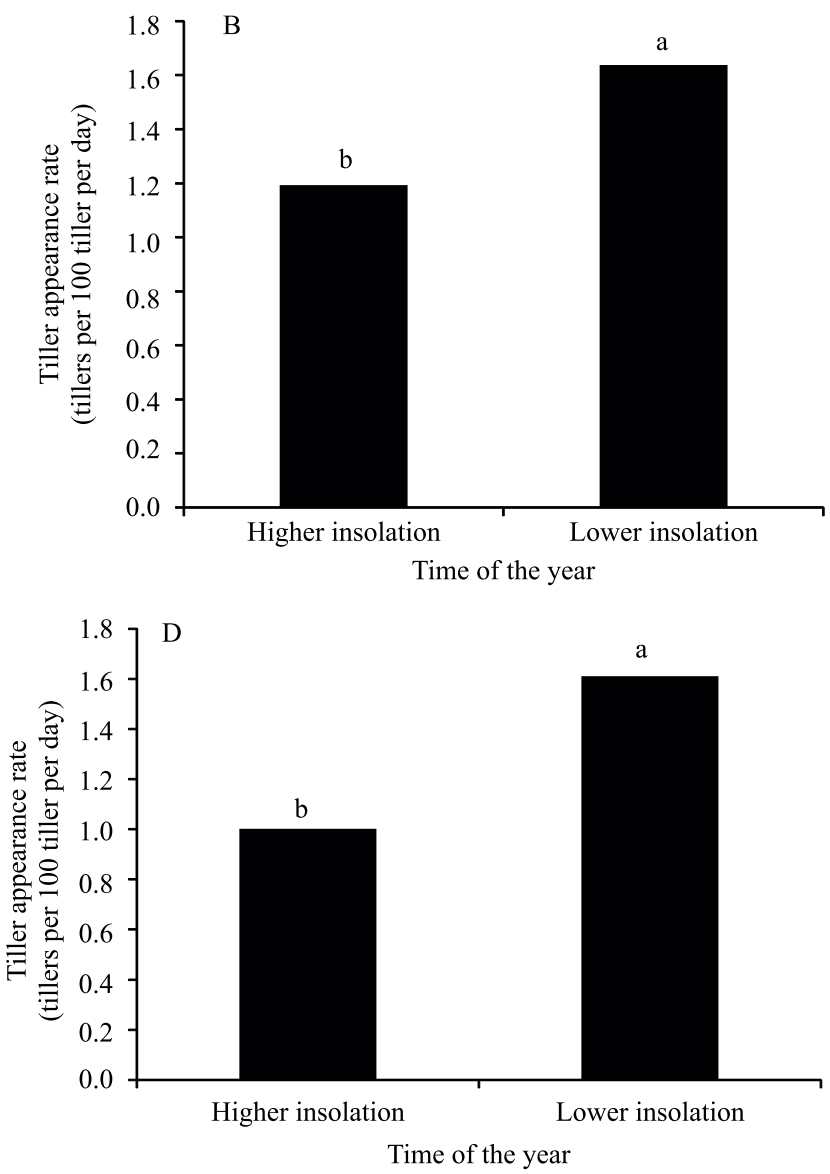

Figure 3. Tiller appearance and mortality rates of 'Suvernola' digit grass (Digitaria eriantha) subjected to four defoliation frequencies (A and C) and different seasons of the year (B and D). Means followed by equal letters do not differ by Student's t-test, at 5\% probability. Defoliation frequencies: very high, $25 \mathrm{~cm}$ in height; high, $35 \mathrm{~cm}$; medium, $45 \mathrm{~cm}$; and low, $55 \mathrm{~cm}$. 
that the survival rate associated with the appearance of tillers offsets the mortality rate, showing an upward trend in the population. By contrast, indices lower than 1.0 indicate that the tiller mortality rate prevails over the survival and appearance rates, which may lead to a decline in tiller population. A stability index of 1.0 suggests that the population is in a stable condition, without the occurrence of increases or decreases in the tiller population (Bahmani et al., 2003).

The fluctuations in the stability index (Figure 5) were not pronounced, remaining around 1.0. Therefore, the alterations recorded in the rates of tiller appearance
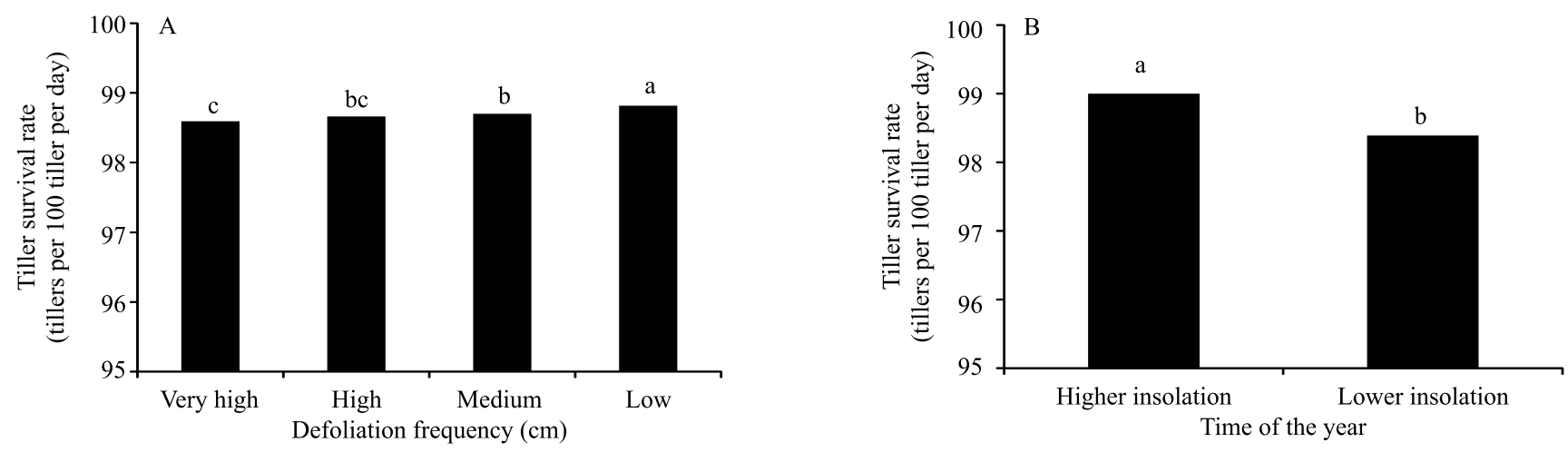

Figure 4. Tiller survival rate of 'Suvernola' digit grass (Digitaria eriantha) subjected to four defoliation frequencies (A) and different seasons of the year (B). Means followed by equal letters do not differ by Student's t-test, at 5\% probability. Defoliation frequencies: very high, $25 \mathrm{~cm}$ in height; high, $35 \mathrm{~cm}$; medium, $45 \mathrm{~cm}$; and low, $55 \mathrm{~cm}$.
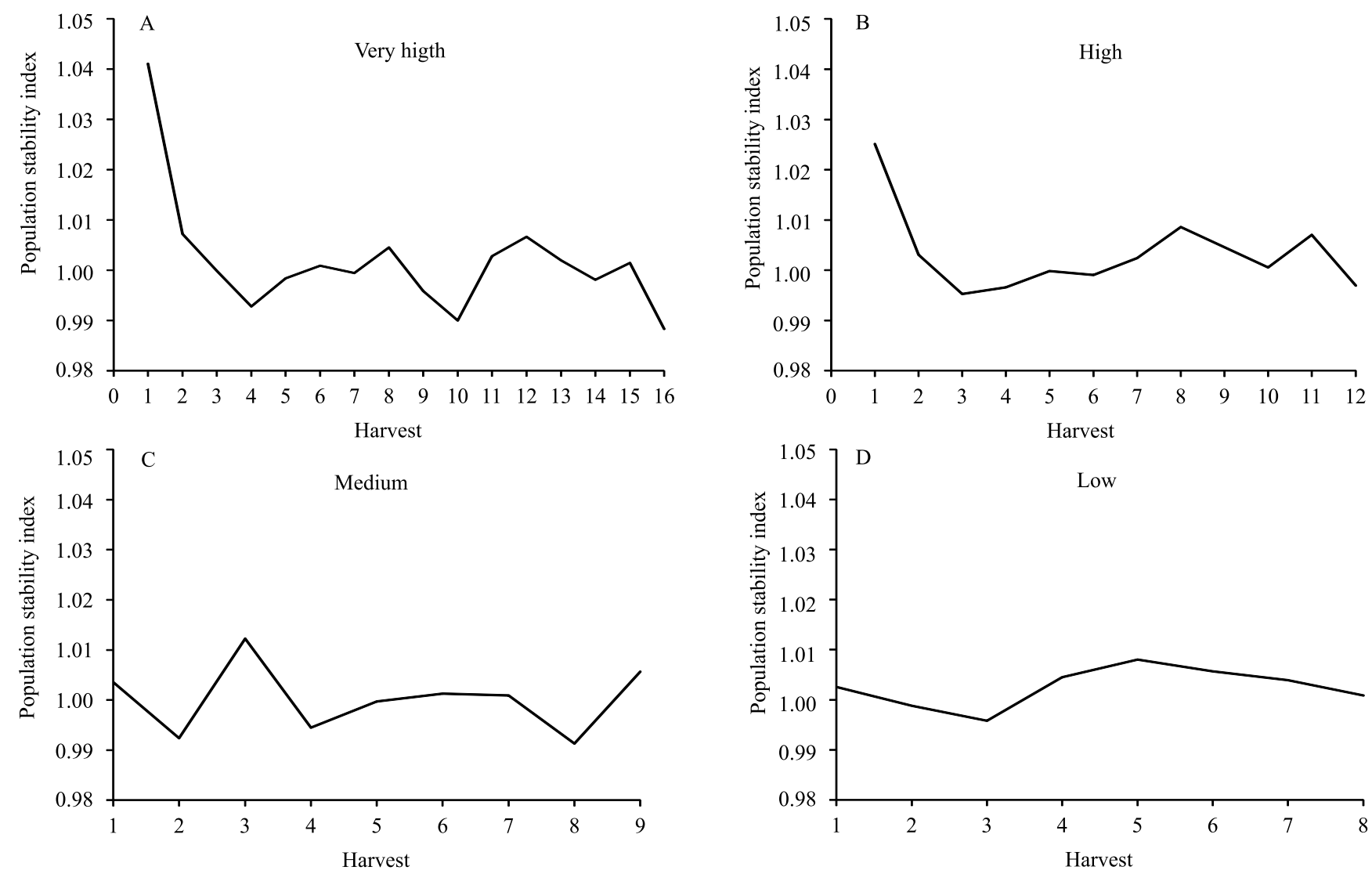

Figure 5. Basal tiller population stability index of 'Suvernola' digit grass (Digitaria eriantha) subjected to the following defoliation frequencies: very high, $25 \mathrm{~cm}$ in height (A); high, $35 \mathrm{~cm}$ (B); medium, $45 \mathrm{~cm}$ (C); and low, $55 \mathrm{~cm}$ (D). 
(Figure $3 \mathrm{~A}$ ), mortality (Figure $3 \mathrm{C}$ ), and survival (Figure $4 \mathrm{~A}$ ), due to the conditions imposed by the treatments, did not compromise population stability or the balance between tiller appearance and mortality. This result indicates that the persistence of the pasture during the evaluation period was significantly affected.

Regarding basal tiller density, there was an interaction between defoliation frequency and period of the year. Regardless of the evaluation period, decreased defoliation frequency reduced basal tiller density (Table 1). At the very high and high defoliation frequencies, basal tiller density was higher in the period of greater insolation. However, in medium and low defoliation frequencies, there was no effect of season of the year (Table 1). Nodal tiller density was also influenced by defoliation frequencies and season of the year. The reduction in defoliation frequencies decreased nodal tiller density (Figure 6 A). It should be noted that tiller density was higher at the time of higher insolation (Figure $6 \mathrm{~B}$ ).

The number of tillers (density) in a plant community is associated with a dynamic and harmonic balance between the processes of tiller appearance and death (Silva et al., 2008). Changes in tiller density occur when the appearance of new tillers exceeds (or not) mortality. However, the tillering ability of a plant decreases as the pasture leaf area increases. In general, pastures managed at greater heights exhibit a larger leaf area and, consequently, intercept more light, reducing the quantity and quality of the light reaching the sward (Silva \& Nascimento Júnior, 2007). This pattern reduces leaf production and the formation of new axillary buds that can generate new tillers. Additionally, the increase in intraspecific competition for light triggers the tiller mortality process, resulting in a dynamic balance

Table 1. Basal tiller density (tillers per square meter) of 'Suvernola' digit grass (Digitaria eriantha) subjected to four defoliation frequencies at different seasons of the year ${ }^{(1)}$.

\begin{tabular}{lccccc}
\hline \multirow{2}{*}{ Period } & \multicolumn{3}{c}{ Defoliation frequency $(\mathrm{cm})^{(2)}$} & \multirow{2}{*}{ SEM } \\
\cline { 2 - 5 } & Very high & High & Medium & Low & \\
\hline $\begin{array}{l}\text { Higher } \\
\text { insolation }\end{array}$ & $775 \mathrm{Aa}$ & $730 \mathrm{Ba}$ & $562 \mathrm{Ca}$ & $528 \mathrm{Ca}$ & 11.10 \\
$\begin{array}{l}\text { Lower } \\
\text { insolation }\end{array}$ & $627 \mathrm{Ab}$ & $608 \mathrm{ABb}$ & $577 \mathrm{Ba}$ & $513 \mathrm{Ca}$ & 11.10 \\
\hline
\end{tabular}

${ }^{(1)}$ Means followed by equal letters do not differ by Student's t-test at, $5 \%$ probability. ${ }^{(2)}$ Defoliation frequencies: very high, $25 \mathrm{~cm}$ in height; high, $35 \mathrm{~cm}$; medium, $45 \mathrm{~cm}$; and low, $55 \mathrm{~cm}$. SEM, standard error of the mean. between the number and weight (size) of tillers (Sbrissia \& Silva, 2008). This decrease in tiller density with increasing defoliation height has also been recorded for other forage plants such as Xaraés (Pedreira et al., 2009), Tanzania (Zanine et al., 2013), and Brachiaria (Portela et al., 2011), among others.

Given the values obtained for the population stability index in the evaluated period (Figure 5), the reduction in basal (Table 1) and nodal tiller (Figure 6) densities as a function of the lower defoliation frequency does not indicate the degradation of digit grass. Therefore, the choice of the defoliation frequency to be adopted
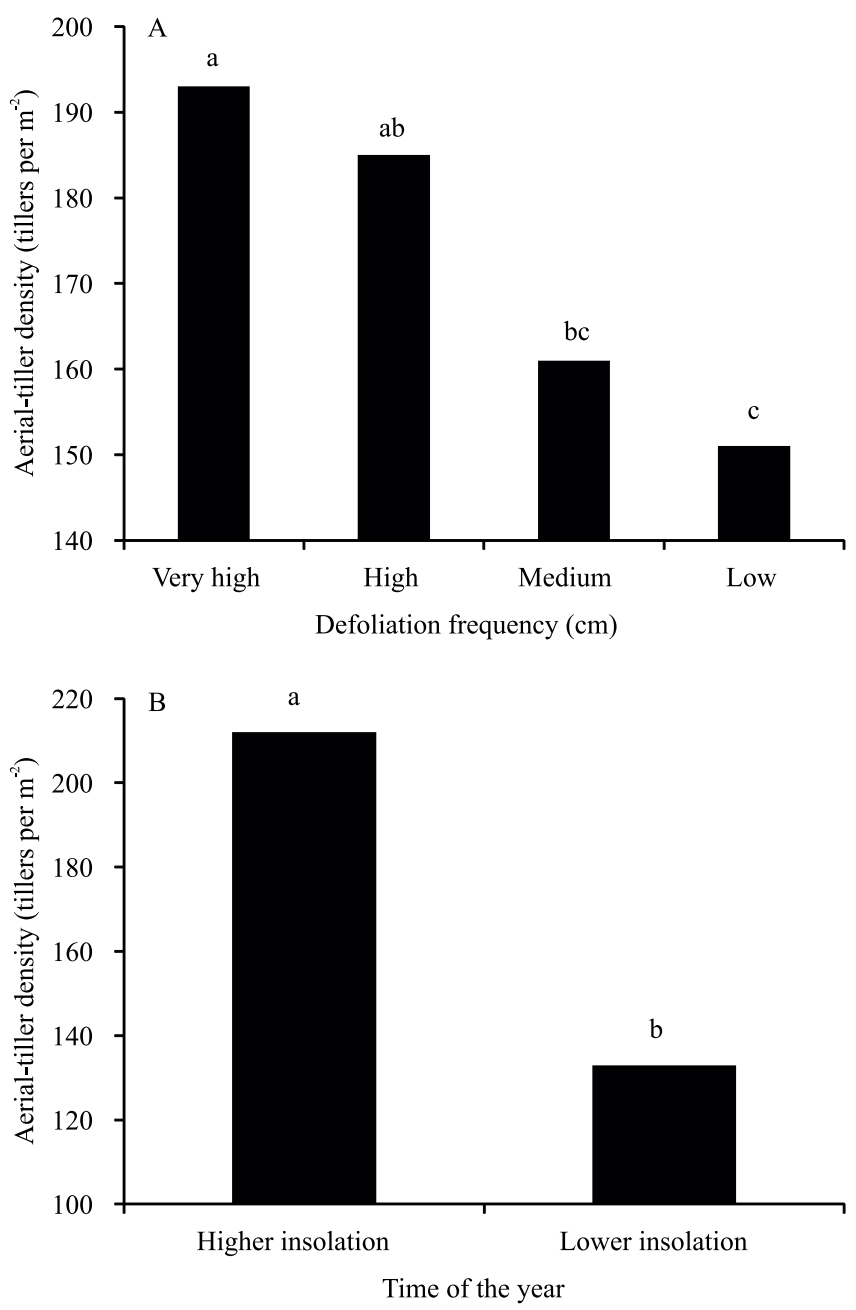

Figure 6. Nodal tiller density of 'Suvernola' digit grass (Digitaria eriantha) subjected to four defoliation frequencies (A) at different times of the year (B). Means followed by equal letters do not differ by Student's t-test, at $5 \%$ probability. Defoliation frequencies: very high, $25 \mathrm{~cm}$ in height; high, $35 \mathrm{~cm}$; medium, $45 \mathrm{~cm}$; and low, $55 \mathrm{~cm}$. 
may be based on other criteria, including productivity, forage quality, and intake and feeding behavior of grazing animals. To this end, new researches with longer periods of evaluation, involving grazing animals, are necessary.

In the period of lower insolation, the grass displayed higher tiller appearance (Figure 3 B) and mortality (Figure $3 \mathrm{D}$ ) rates, besides a lower survival rate (Figure $4 \mathrm{~B}$ ). In the state of Sergipe, the period of lower insolation coincides with winter and continues throughout the months of April to August (Figure 1 A), with lower insolation and average temperatures (Figure $1 \mathrm{~A}$ ) and higher precipitation (Figure $1 \mathrm{~B}$ ) and nebulosity. Therefore, digit grass was possibly benefited by the milder temperature conditions and higher precipitation in the period of lower insolation, which promoted a higher tiller appearance rate (Figure $3 \mathrm{~B}$ ) and, consequently, a lower mortality rate (Figure 3 D) as a compensatory mechanism for the maintenance of the tiller population, resulting in lower survival in this period (Figure 4 B). According to Sbrissia et al. (2010), in times of the year when soil-climatic conditions are less limiting, plants potentiate their growth through higher tiller appearance and survival rates, resulting in lower longevity but in more productive generations. This pattern leads to a greater tissue renewal in the pasture. As discussed previously, this greater tissue renewal may favor a younger tiller population, which may then result in plants with higher nutritional value, improving animal performance.

In the period of higher insolation, basal tiller density at very high and high defoliation frequencies (Table 1) and nodal tiller density (Figure 6 B) were higher than in the period of lower insolation. Because water availability was not a limiting factor, the greater basal and nodal tiller densities may be related to tiller survival, since higher survival rates (Figure $4 \mathrm{~B}$ ) and balance between appearance and mortality were observed in the period of higher insolation.

\section{Conclusions}

1. The evaluated defoliation frequencies and seasons of the year do not change the population stability of 'Suvernola' digit grass (Digitaria eriantha) when irrigated, ensuring its persistence.

2. Higher defoliation frequencies result in greater tiller renewal in digit grass.

\section{Acknowledgments}

To Coordenação de Aperfeiçoamento de Pessoal de Nível Superior (Capes, Finance Code 001), to Conselho Nacional de Desenvolvimento Científico e Tecnológico $(\mathrm{CNPq})$, and to Fundação de Apoio à Pesquisa e à Inovação Tecnológica do Estado de Sergipe (Fapitec), for financial support.

\section{References}

BAHMANI, I.; THOM, E.R.; MATTHEW, C.; HOOPER, R.J.; LEMAIRE, G. Tiller dynamics of perennial ryegrass cultivars derived from different New Zealand ecotypes: effects of cultivar, season, nitrogen fertiliser, and irrigation. Australian Journal of Agricultural Research, v.54, p.803-817, 2003. DOI: https://doi. org/10.1071/AR02135.

BARBOSA, R.A.; NASCIMENTO JÚNIOR, D. do; VILELA, H.H.; SOUSA, B.M. de L.; SILVA, S.C. da; EUCLIDES, V.P.B.; SILVEIRA, M.C.T. da. Morphogenetic and structural characteristics of Guinea grass tillers at different ages under intermittent stocking. Revista Brasileira de Zootecnia, v.41, p.1583-1588, 2012. DOI: https://doi.org/10.1590/S151635982012000700005 .

CAMINHA, F.O.; SILVA, S.C. da; PAIVA, A.J.; PEREIRA, L.E.T.; MESQUITA, P. de; GUARDA, V.D.A. Estabilidade da população de perfilhos de capim-marandu sob lotação contínua e adubação nitrogenada. Pesquisa Agropecuária Brasileira, v.45, p.213-220, 2010. DOI: https://doi.org/10.1590/S0100-204X2010000200013.

COOK, B.G., SCHULTZE-KRAFT, R. Botanical name changes nuisance or a quest for precision? Tropical Grasslands - Forrajes Tropicales, v.3, p.34-40, 2015. DOI: https://doi.org/10.17138/ TGFT(3)34-40.

DIFANTE, G. dos S.; NASCIMENTO JÚNIOR, D. do; SILVA, S.C. da; EUCLIDES, V.P.B.; ZANINE, A. de M.; ADESE, B. Dinâmica do perfilhamento do capim-marandu cultivado em duas alturas e três intervalos de corte. Revista Brasileira de Zootecnia, v.37, p.189-196, 2008. DOI: https://doi.org/10.1590/ S1516-35982008000200003.

GIMENES, F.M. de A.; SILVA, S.C. da; FIALHO, C.A.; GOMES, M.B.; BERNDT, A.; GERDES, L.; COLOZZA, M.T. Ganho de peso e produtividade animal em capim-marandu sob pastejo rotativo e adubação nitrogenada. Pesquisa Agropecuária Brasileira, v.46, p.751-759, 2011. DOI: https://doi.org/10.1590/ S0100-204X2011000700011.

GUSMÃO FILHO, J.D. Digitaria eriantha cv. Survenola submetido à alturas de desfolhação. 2018. 60p. Tese (Doutorado) - Universidade Estadual do Sudoeste da Bahia, Itapetinga.

MATTHEW, C.; ASSUERO, S.G.; BLACK, C.K.; SACKVILLE HAMILTON, N.R. Tiller dynamics of grazed swards. In: LEMAIRE, G.; HODGSON, J.; MORAES, A.; CARVALHO, P.C.F.; NABINGER, C. (Ed.). Grassland ecophysiology and grazing ecology. Wallingford: CABI, 2000, p.127-150. DOI: https://doi.org/10.1079/9780851994529.0127. 
MONTAGNER, D.B.; NASCIMENTO JÚNIOR, D. do; VILELA, H.H.; SOUSA, B.M. de L.; EUCLIDES, V.P.B.; SILVA, S.C. da; CARLOTO, M.N. Tillering dynamics in pastures of guinea grass subjected to grazing severities under intermittent stocking. Revista Brasileira de Zootecnia, v.41, p.544-549, 2012. DOI: https://doi.org/10.1590/S1516-35982012000300010.

NAVARRO, L.; RODRÍGUEZ, I.; GONZÁLEZ, S.; TORRES, A. Umfolozi o pangola peluda: un pasto que comienza a ser cultivado. INIA Divulga, v.4, p.29-32, 2005.

OLIVEIRA, V.S.; MORAIS, J.A. da S.; FAGUNDES, J.L.; SANTANA, J.C. dos S.; LIMA, I.G.S.; SANTOS, C.B. Produção e composição químico-bromatológica de gramíneas tropicais submetidas a dois níveis de irrigação. Archives of Veterinary Science, v.20, p.27-36, 2015. DOI: https://doi.org/10.5380/avs. v20i2.36337.

PAIVA, A.J.; SILVA, S.C. da; PEREIRA, L.E.T.; GUARDA, V.D.A.; PEREIRA, P. de M.; CAMINHA, F.O. Structural characteristics of tiller age categories of continuously stocked Marandu palisade grass swards fertilized with nitrogen. Revista Brasileira de Zootecnia, v.41, p.24-29, 2012. DOI: https://doi. org/10.1590/S1516-35982012000100004.

PEDREIRA, B.C. e; PEDREIRA, C.G.S.; SILVA, S.C. da. Acúmulo de forragem durante a rebrotação de capim-xaraés submetido a três estratégias de desfolhação. Revista Brasileira de Zootecnia, v.38, p.618-625, 2009. DOI: https://doi.org/10.1590/ S1516-35982009000400005.

PORTELA, J.N.; PEDREIRA, C.G.S.; BRAGA, G.J. Demografia e densidade de perfilhos de capim-braquiária sob pastejo em lotação intermitente. Pesquisa Agropecuária Brasileira, v.46, p.315-322, 2011. DOI: https://doi.org/10.1590/S0100204X2011000300013.

SANTANA, S.S.; FONSECA, D.M. da; SANTOS, M.E.R.; SOUSA, B.M. de L.; GOMES, V.M.; NASCIMENTO JÚNIOR, D. do. Initial height of pasture deferred and utilized in winter and tillering dynamics of signal grass during the following spring. Acta Scientiarum. Animal Sciences, v.36, p.17-23, 2014. DOI: https://doi.org/10.4025/actascianimsci.v36i1.20463.

SANTOS, H.G. dos; JACOMINE, P.K.T.; ANJOS, L.H.C. dos; OLIVEIRA, V.A. de; OLIVEIRA, J.B. de; COELHO, M.R.; LUMBRERAS, J.F.; CUNHA, T.J.F. (Ed.). Sistema brasileiro de classificação de solos. 2.ed. Brasília: Embrapa, 2006. 306p.

SBRISSIA, A.F.; SILVA, S.C. da. Aspectos relacionados à produção de forragem e o processo de pastejo. In: SIMPÓSIO SOBRE MANEJO ESTRATÉGICO DA PASTAGEM, 7.; SIMPÓSIO INTERNACIONAL SOBRE PRODUÇÃO ANIMAL EM PASTEJO, 5., 2014, Viçosa. Anais. Viçosa: Suprema, 2014. p.1-26.
SBRISSIA, A.F.; SILVA, S.C. da. Compensação tamanho/ densidade populacional de perfilhos em pastos de capimmarandu. Revista Brasileira de Zootecnia, v.37, p.35-47, 2008. DOI: https://doi.org/10.1590/S1516-35982008000100005.

SBRISSIA, A.F.; SILVA, S.C. da; SARMENTO, D.O.L.; MOLAN, L.K.; ANDRADE, F.M.E.; GONÇALVES, A.C.; LUPINACCI, A.V. Tillering dynamics in palisadegrass swards continuously stocked by cattle. Plant Ecology, v.206, p.349-359, 2010. DOI: https://doi.org/10.1007/s11258-009-9647-7.

SILVA, S.C. da; NASCIMENTO JÚNIOR, D. do. Avanços na pesquisa com plantas forrageiras tropicais em pastagens: características morfofisiológicas e manejo do pastejo. Revista Brasileira de Zootecnia, v.36, p.122-138, 2007. Suplemento especial. DOI: https://doi.org/10.1590/S1516-35982007001000014.

SILVA, S.C. da; NASCIMENTO JÚNIOR, D. do; SBRISSIA, A.F.; PEREIRA, L.E.T. Dinâmica de população de plantas forrageiras em pastagens. In: SIMPÓSIO SOBRE MANEJO ESTRATÉGICO DA PASTAGEM, 4.; SIMPÓSIO INTERNACIONAL SOBRE PRODUÇÃO ANIMAL EM PASTEJO, 2., 2008, Viçosa. Anais. Viçosa: UFV, 2008. p.75-99. Editado por: Odilon G. Pereira, José Antonio Obeid, Dilermando Miranda Fonseca, Domicio do Nascimento Júnior.

SOUSA, B.M.L.; NASCIMENTO JÚNIOR, D. do; MONTEIRO, H.C. de F.; SILVA, S.C. da; VILELA, H.H.; SILVEIRA, M.C.T. da; RODRIGUES, C.S.; SBRISSIA, A.F. Dynamics of forage accumulation in Elephant grass subjected to rotational grazing intensities. Revista Brasileira de Zootecnia, v.42, p.629-638, 2013. DOI: https://doi.org/10.1590/S1516-35982013000900004.

SOUZA, L.J.N.; SANTOS, D.B.O.; FAGUNDES, J.L.; SOUZA, B.M.L.; BACKES, A.A.; OLIVEIRA JÚNIOR, L.F.G.; SANTOS, A.D.F.; MOREIRA, A.L. Morfogênese do capim faixa-branca submetido à adubação nitrogenada. Boletim de Indústria Animal, v.73, p.281-289, 2016. DOI: https://doi.org/10.17523/bia. v73n4p281.

VOLTOLINI, T.V.; SANTOS, F.A.P.; MARTINEZ, J.C.; CLARINDO, R.L.; PENATI, M.A.; IMAIZUMI, H. Características produtivas e qualitativas do capim-elefante pastejado em intervalo fixo ou variável de acordo com a interceptação da radiação fotossinteticamente ativa. Revista Brasileira de Zootecnia, v.39, p.1002-1010, 2010. DOI: https:// doi.org/10.1590/S1516-35982010000500009.

ZANINE, A. de M.; NASCIMENTO JÚNIOR, D. do; SOUSA, B.M. de L.; SILVEIRA, M.C.T. da; SILVA, W.L. da; SANTOS, M.E.R. Tillering dynamics in Guinea grass pastures subjected to management strategies under rotational grazing. Revista Brasileira de Zootecnia, v.42, p.155-161, 2013. DOI: https://doi. org/10.1590/S1516-35982013000300002. 